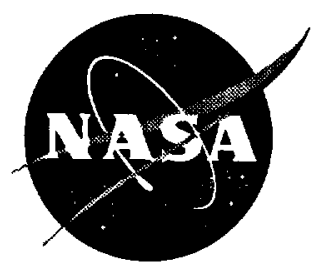

\title{
Recent Flight Test Results of the Joint CIAM- NASA Mach 6.5 Scramjet Flight Program
}

Alexander S. Roudakov and Vyacheslav L. Semenov

Central Institute of Aviation Motors

Moscow, Russia

John W. Hicks

NASA Dryden Flight Research Center

Edwards, California

National Aeronautics and

Space Administration

Dryden Flight Research Center

Edwards, California 93523-0273 


\section{NOTICE}

Use of trade names or names of manufacturers in this document does not constitute an official endorsement of such products or manufacturers, either expressed or implied, by the National Aeronautics and Space Administration.

Available from the following:

NASA Center for AeroSpace Information (CASI) 7121 Standard Drive

Hanover, MD 21076-1320

(301) 621-0390
National Technical Information Service (NTIS) 5285 Port Royal Road Springfield, VA 22161-2171 (703) $487-4650$ 


\title{
RECENT FLIGHT TEST RESULTS OF THE JOINT CIAM-NASA MACH 6.5 SCRAMJET FLIGHT PROGRAM
}

\author{
Alexander S. Roudakov ${ }^{*}$ and Vyacheslav L. Semenov ${ }^{*}$ \\ Central Institute of Aviation Motors \\ Moscow, Russia \\ John W. Hicks ${ }^{\dagger}$ \\ NASA Dryden Flight Research Center \\ Edwards, California, USA
}

\begin{abstract}
$\underline{\text { Abstract }}$
Under a contract with NASA, a joint Central Institute of Aviation Motors (CIAM) and NASA team recently conducted the fourth flight test of a dual-mode scramjet aboard the CIAM Hypersonic Flying Laboratory, "Kholod." With an aim test Mach 6.5 objective, the successful launch was conducted at the Sary Shagan test range in central Kazakstan on February 12, 1998. Ground-launch, rocket boosted by a modified Russian SA5 missile, the redesigned scramjet was accelerated to a new maximum velocity greater than Mach 6.4 . This launch allowed for the measurement of the fully supersonic combustion mode under actual flight conditions. The primary program objective was the flight-to-ground correlation of measured data with preflight analysis and wind-tunnel tests in Russia and potentially in the United States. This paper describes the development and objectives of the program as well as the technical details of the scramjet and SA5 redesign to achieve the Mach 6.5 aim test condition. An overview of the launch operation is also given. Finally, preliminary flight test results are presented and discussed.
\end{abstract}

\section{Introduction}

Internationally, several countries, such as the United States, Japan, France, Germany, and Russia, have been involved individually and jointly in the development of air-breathing propulsion technology solutions to efficient, low-cost, point-to-point rapid global access and

\footnotetext{
* Member, AIAA.

Associate Fellow, AIAA

Copyright (C) 1998 by the American Institute of Aeronautics and Astronautics, Inc. No copyright is asserted in the United States under Title 17, U.S. Code. The U.S. Government has a royalty-free license to exercise all rights under the copyright claimed herein for Governmental purposes. All other rights are reserved by the copyright owner.
}

space transportation. The scramjet, its performance potential, and its design methodology validation have been at the center of this quest. Programs, such as this joint Russian-American project, seek to address this last major aeronautics frontier.

Previously, the Central Institute of Aviation Motors (CIAM), Moscow, Russia, conducted three rocketboosted flight tests of its axisymmetric dual-mode Mach 6 design scramjet (fig. 1). The first was in November 1991, and the second involved a joint project with the French in November 1992. These flights achieved approximately Mach 5.5 and Mach 5.35, respectively (ref. 1). The third attempt was also with the French. In this March 1995 attempt, the engine failed to operate because of some onboard power system problems; however, non-fueled cold flow engine data were obtained to Mach 5.8. All scramjet flights were flown captive-carry atop the SA5 surface-to-air missile that included an experimental flight support unit known as the Hypersonic Flying Laboratory (HFL), "Kholod." 1

In November 1994, NASA contracted with CIAM to continue exploring the scramjet operating envelope from the ram-scram, dual-mode operation below Mach 6 to the full supersonic combustion (scram) mode at Mach 6.5. To accomplish this objective, the higher heat loads required redesign of the scramjet combustor and active cooling system. Likewise, the increase to Mach 6.5 required modifications to the SA5 booster to reduce drag and to improve performance. The contract specified the building of four identical engines to accomplish all required ground and flight tests. The first two engines were dedicated to wind-tunnel tests up to Mach 6.5 simulated flight conditions. The third was designated for flight test, and the fourth acted as a backup flight test engine. The NASA ground testing of one of the first two engines at the NASA Langley Research Center, Hampton, Virginia, is planned after completion of the flight phase. The CIAM C16 V/K methane-heated 


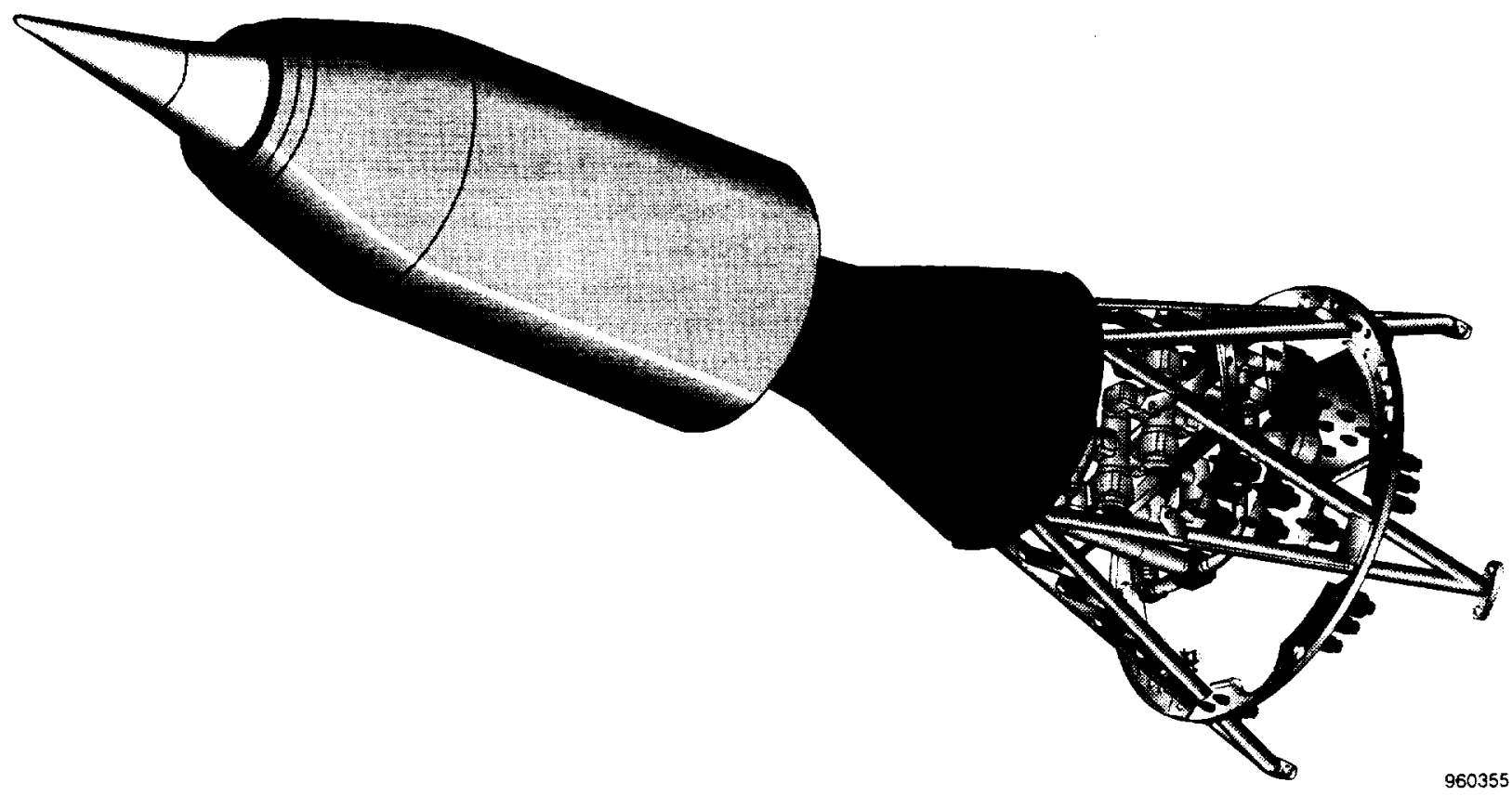

Figure 1. Artist's conception of scramjet external view.

vitiated wind tunnel (fig. 2) was upgraded to provide extended test time with a new facility nozzle and to test a complete full-scale engine to the test conditions listed in table 1 .

Table 1. Test conditions.

\begin{tabular}{|c|c|c|}
\hline & $\begin{array}{l}\text { Ramjet } \\
\text { mode }\end{array}$ & $\begin{array}{l}\text { Scramjet } \\
\text { mode }\end{array}$ \\
\hline Hydrogen consumption, $\mathrm{kg} / \mathrm{sec}$ & 0.3 & 1.4 \\
\hline Air mass flow rate, $\mathrm{kg} / \mathrm{sec}$ & 20 & 30 \\
\hline Air temperature, $\mathrm{K}$ & 2000 & 2500 \\
\hline $\begin{array}{l}\text { Air pressure at aerodynamic } \\
\text { nozzle entrance, } \mathrm{MPa}\end{array}$ & $1.0-7.5$ & 20 \\
\hline $\begin{array}{l}\text { Air flow Mach number at } \\
\text { nozzle exit, MPa }\end{array}$ & 3.6 & 8 \\
\hline Test duration, sec & 30 & 30 \\
\hline
\end{tabular}

The overall program objectives were to explore and measure the full supersonic combustion mode and to correlate these flight data with ground tests and with analysis techniques. These objectives included the opportunities to validate design and analysis methods and to compare NASA and CIAM ground test facility test techniques and results. This comparison was conducted with a common set of instrumentation sensors and measurement locations to facilitate data correlation activities with predictive analysis results.

Another key objective in the joint nature of the program was to involve NASA engineering personnel in as much of the research, analysis, and testing as possible. Besides the comparison of results, methodologies, and test techniques between the two organizations, this program gave NASA a direct opportunity to learn about Russian facilities and test techniques. An additional advantage is that NASA has provided an independent assessment of the engine design, instrumentation, and ground facility operation to CIAM. ${ }^{2}$

\section{Hypersonic Flying Laboratory, "Kholod"}

The HFL, "Kholod," comprises the entire experimental system, including the scramjet engine and propellant, engine control, engine cooling, instrumentation, and telemetry systems. This laboratory was designed to essentially replace the size and mass of the original SA5 payload.

Figure 3 shows a schematic of the complete HFL. The HFL consists of three main support compartments: N1, $\mathrm{N} 2$, and N3A/B aft of the engine. The conical N1 compartment comprises a transition section from the engine to the cylindrical booster and is covered by a 


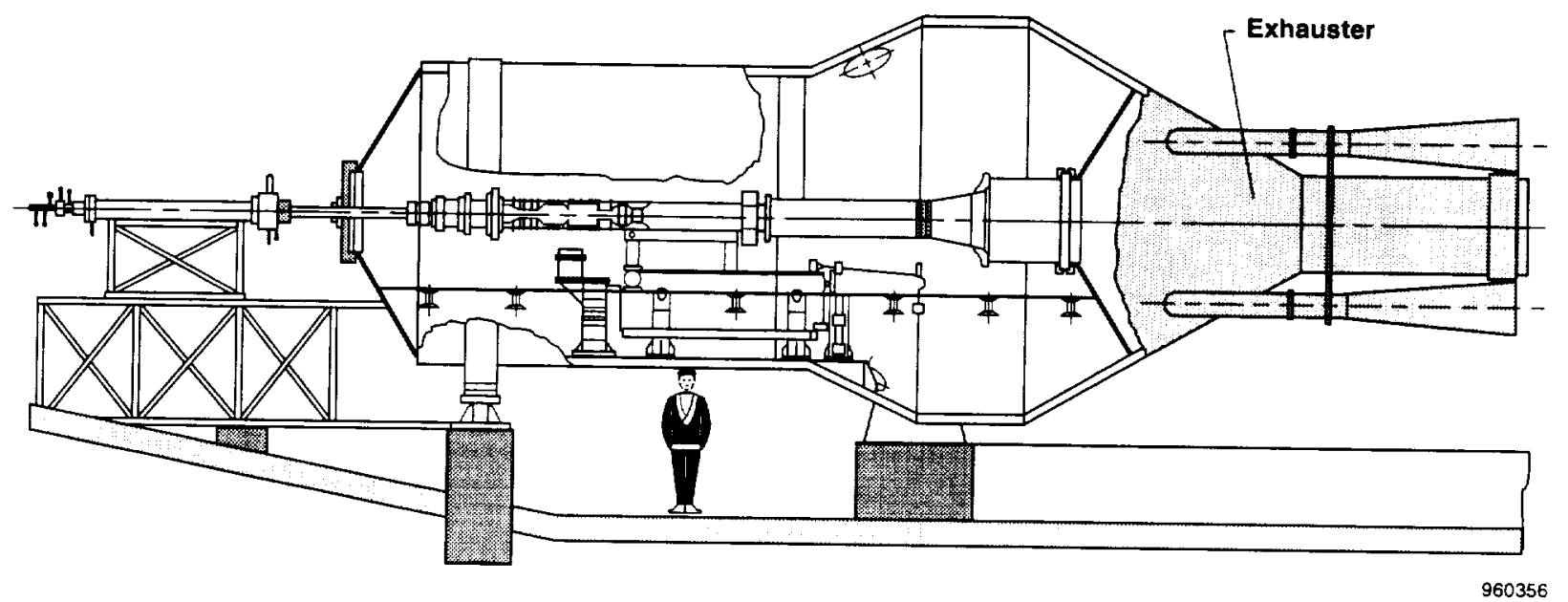

Figure 2. The C-16 CIAM V/K facility for scramjet large-scale models test.

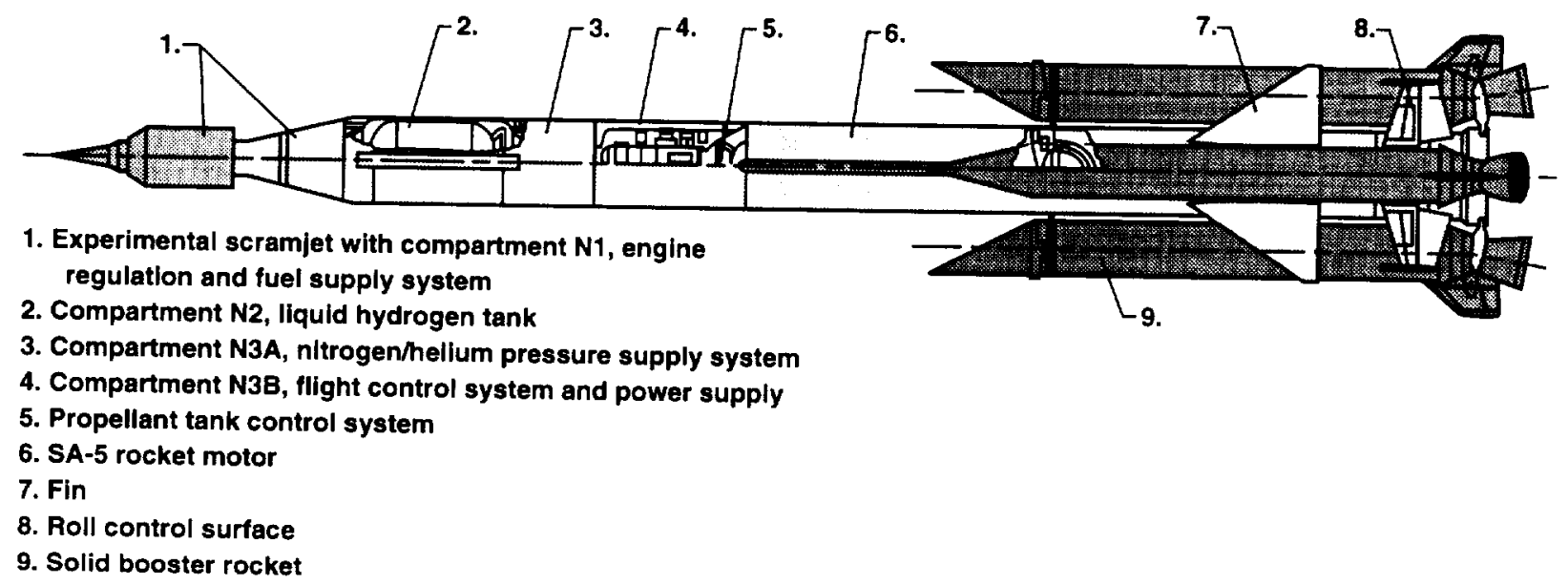

Figure 3. The Hypersonic Flying Laboratory.

thermal protective skin to shield it from the engine exhaust. This compartment contains the engine control, fuel regulator, and instrumentation systems. Compartment N2 contains the double-walled, insulated liquid hydrogen propellant tank, followed by the N3A compartment containing the pressurized helium bottle used to pump the fuel to the engine. The N3A compartment also contains the high-pressure nitrogen bottle used for the pneumatic actuators. The final N3B compartment contains the telemetry system, system batteries, and SA5 missile control system.

Onboard HFL instrumentation includes 83 pressure transducers; 43 of which measure engine duct wall pressures. There are 58 thermocouples; 38 of which are located along the engine duct. In addition, 46 other system operation sensors are included in the instrumentation. Figure 4 shows the main engine flowpath instrumentation. The majority of these data are telemetered at a digital 50 samples/sec except for the frequency modulation analog temperature measurements which are transmitted at $1.5 \mathrm{~Hz}$. NASA has contributed additional instrumentation to compare with or enhance the Russian measurement system. This instrumentation included a body-mounted, three-axis, orthogonal accelerometer package and several flowpath pressure transducers. 

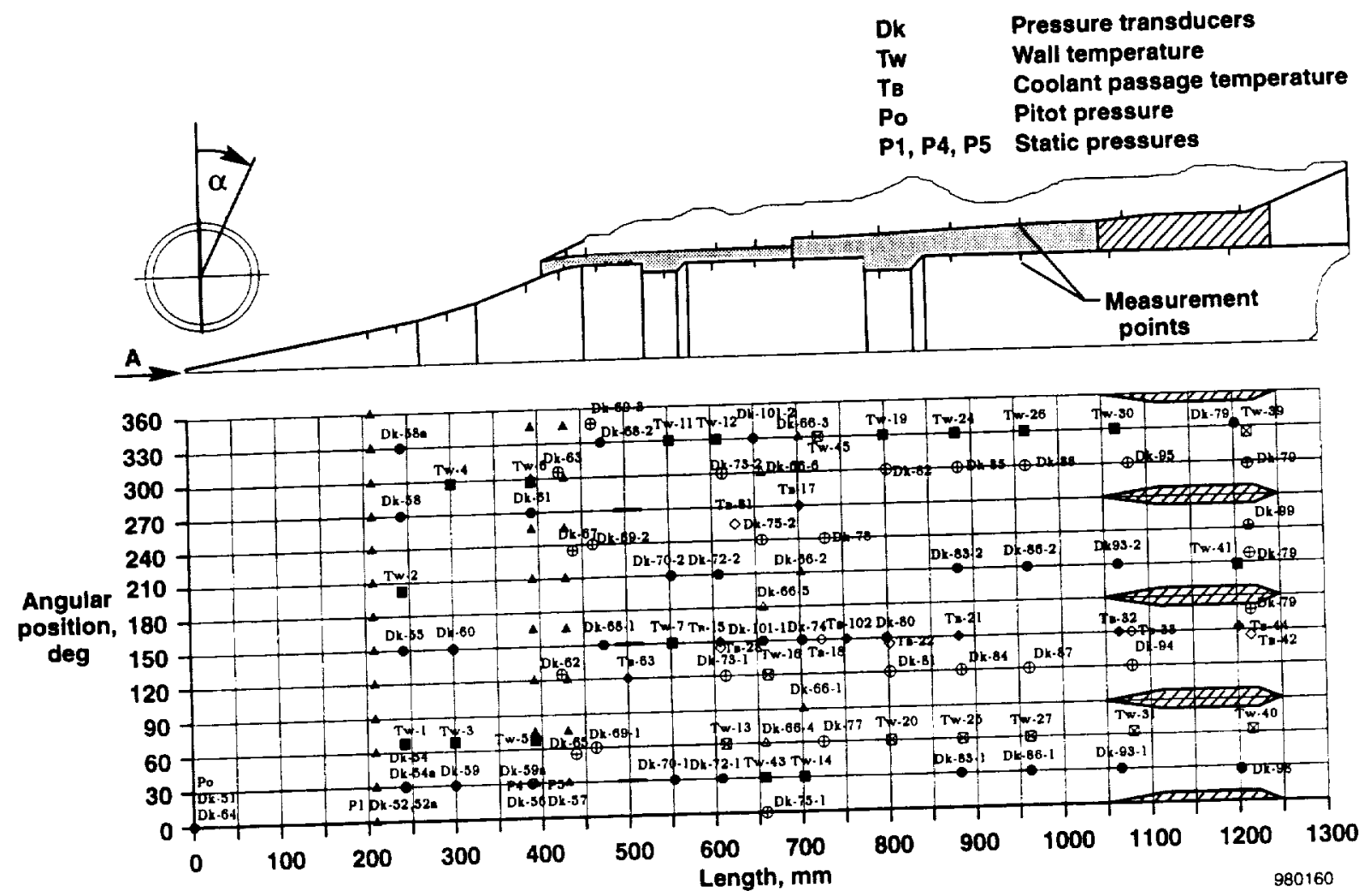

Figure 4. The scramjet flowpath instrumentation layout.

\section{Axisymmetric Scramjet Description and Redesign}

The hydrogen-fueled axisymmetric model $58 \mathrm{~L}$ scramjet (fig. 5) is basically a CIAM Mach 6 design with modifications to the combustor, inlet leading edge, and cooling system to allow testing at Mach 6.5. The fixedgeometry spike inlet consists of three conical section compression ramps set at $10^{\circ}, 15^{\circ}$, and $20^{\circ}$ ramp onehalf angles. This geometry generates a single shock-onlip condition at Mach 6 on the inlet leading edge or cowl lip, allowing for a slightly oversped flow condition at Mach 6.5. This inlet design was deemed to yield satisfactory engine performance without having to redesign and retest the entire inlet.

The inlet spike and inlet leading edge were uncooled, but the EP666 stainless steel alloy material was replaced on the leading edge with a new steel-chromiumaluminum alloy called Fekral. This new material was necessary because analysis revealed excessive temperatures would be obtained for the leading-edge material at Mach 6.5 compared to past flights. Such temperatures exceed the capability of the EP666 steel. The new Fekral material has approximately the same low thermal conductivity as the EP666 steel. However, its greatly increased heat capacity allows Fekral to survive longer at the elevated temperatures to complete the aim test conditions of about $5 \mathrm{sec}$ at Mach 6.5. The external cowl is coated with a chromium-nickel spray near the front to increase heat emissivity to 0.90 .

In the combustor area (fig. 6), the isolator between the inlet throat and the first fuel injector station was lengthened $33 \mathrm{~mm}$ to reduce inlet and combustor interaction. The combustor section between the first and second fuel injector stations was lengthened by $45 \mathrm{~mm}$ for improved combustion stability and efficiency. A final third row of fuel injectors completes that section before entering a truncated internal nozzle section. Wallmounted fuel injectors at stations 1 and 2 were set at a $30^{\circ}$ angle to the combustor duct axis. Each station has 40 fuel injectors of $1.7-$ and $2.1-\mathrm{mm}$ diameter, respectively, distributed annularly about the engine. Similarly, 40 station 3 injectors of $2.1-\mathrm{mm}$ diameter are set at $45^{\circ}$ to the combustor duct axis. Each injector station is followed by a flame holder cavity containing dual electronic spark igniters that operate continuously. The flame holder cavity at the second injector station was modified to a simple aft-facing step to reduce internal drag levels. 


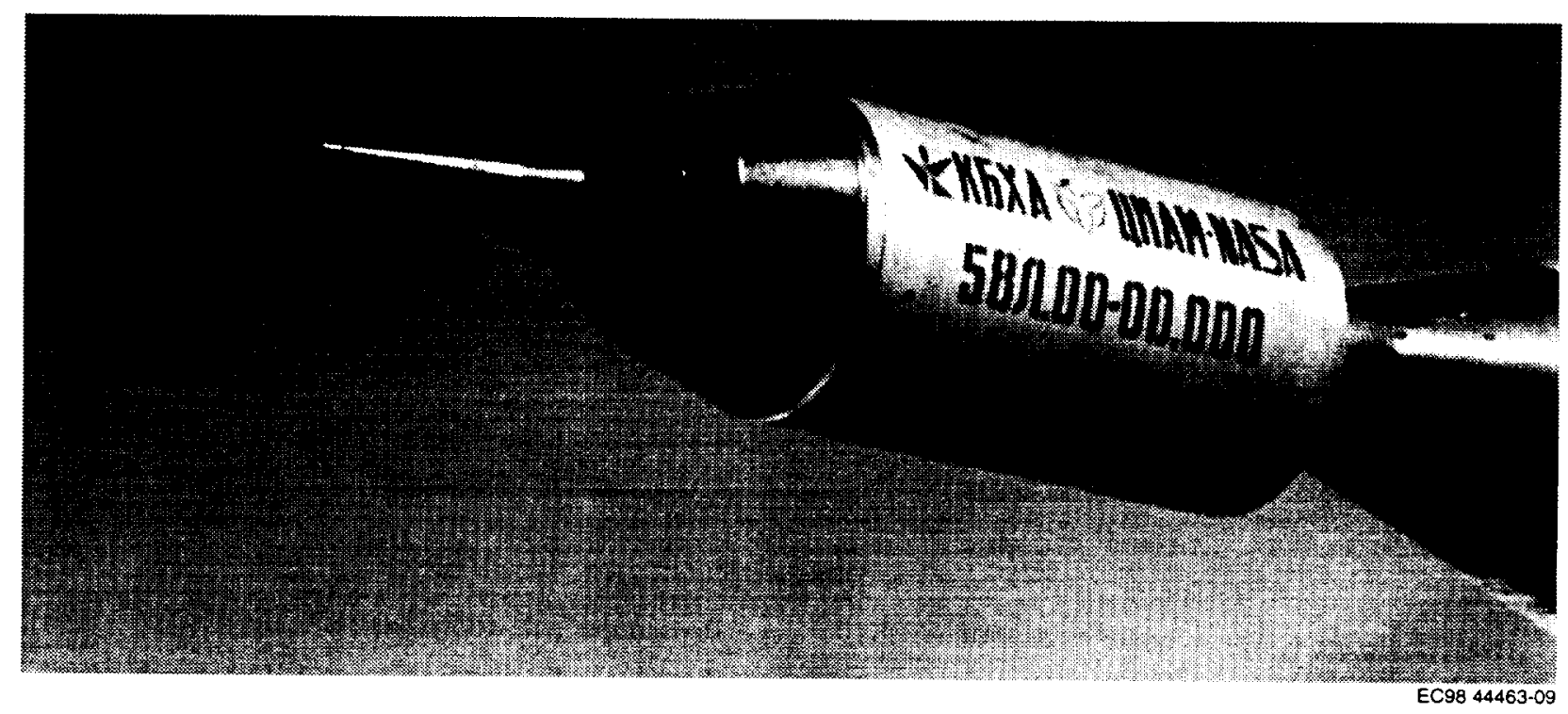

(a) Side view.

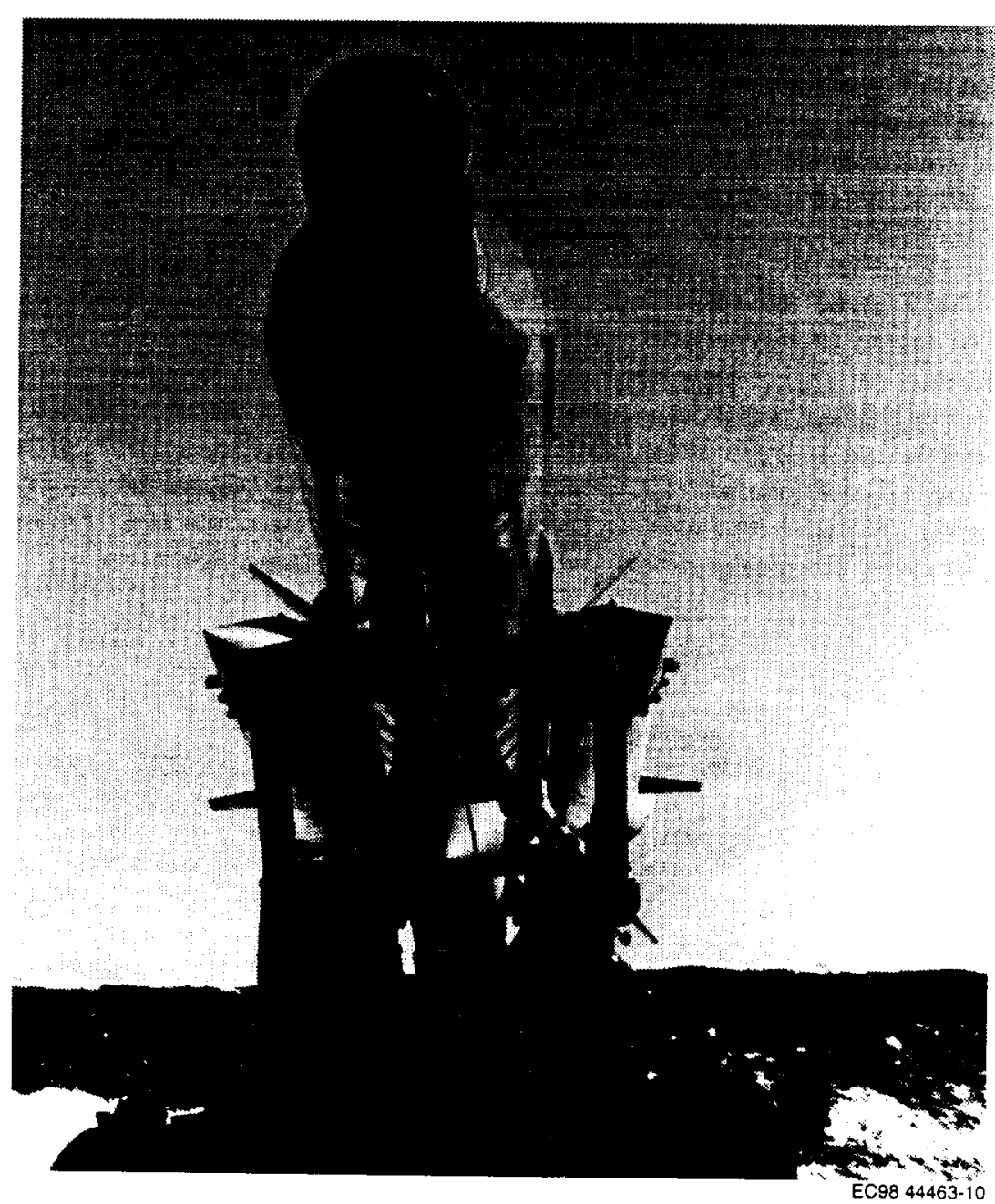

(b) Front view.

Figure 5. The CIAM Mach 6.5, model 58L, flight test scramjet. 


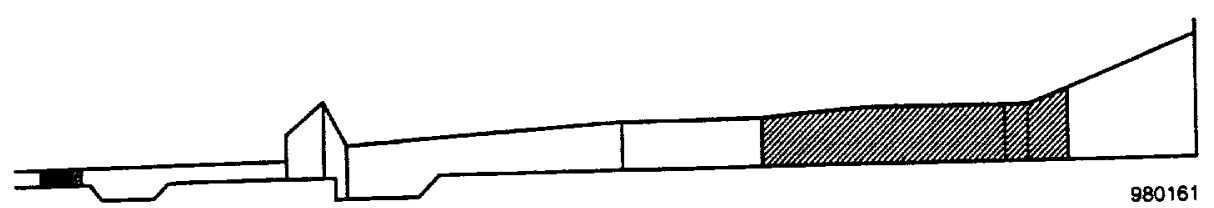

(a) Scramjet model 57.

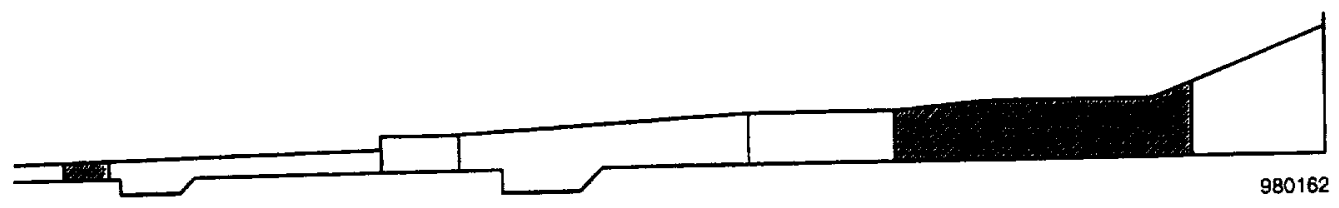

(b) Scramjet model 58L.

Figure 6. The scramjet model 58L combustor geometry comparison with previous model 57 .

The engine cowl structure is attached to the center body structure by three uncooled steel struts in the front part of the engine and four load-bearing struts in the aft part of the engine. Fuel lines, pressure and thermocouple measurement lines, and electric spark plug wiring are routed through the aft struts from the central body to the cowl. The aft struts are made of molybdenum coated with silicone dioxide for heat protection.

Liquid hydrogen direct from the propellant tank circulates through the engine as regenerative coolant before being injected into the engine for combustion. The combustor area cooling system was modified (fig 7) to increase its efficiency before injection of the gaseous hydrogen fuel. The engine cowl-side and the central body-side hot walls of the flowpath have a new modified copper alloy liner containing chemically milled 2 - by 2-mm longitudinal cooling channels. The central body side contains 200 cooling channels; meanwhile, the cowl side contains 280 channels. The cold internal or back side of the cooling liner is an all-steel skin silver soldered to the hot side copper. For practical manufacturing and component integration purposes, small sections of the hot side cooling liner were left as stainless steel for instrumentation sensor installation and in the front section of the flame holders for fuel injector installation. The internal nozzle section aft of the last support pylon was also left as an all-steel cooling liner. The entire engine, including internally routed sensors, lines, and valves, was then welded together in a single, unitized construction. All lines and instrumentation wiring were then run out the aft end of the engine center body to the rest of the HFL. Engine characteristics are summarized in table 2 :

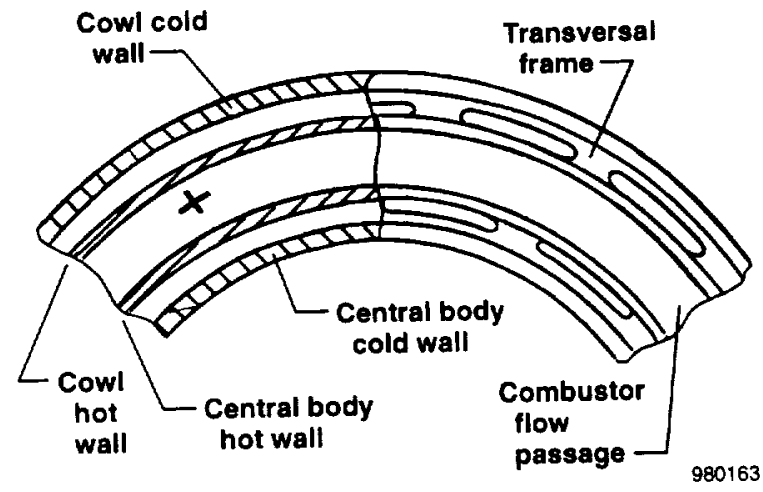

(a) Scramjet model 57 .

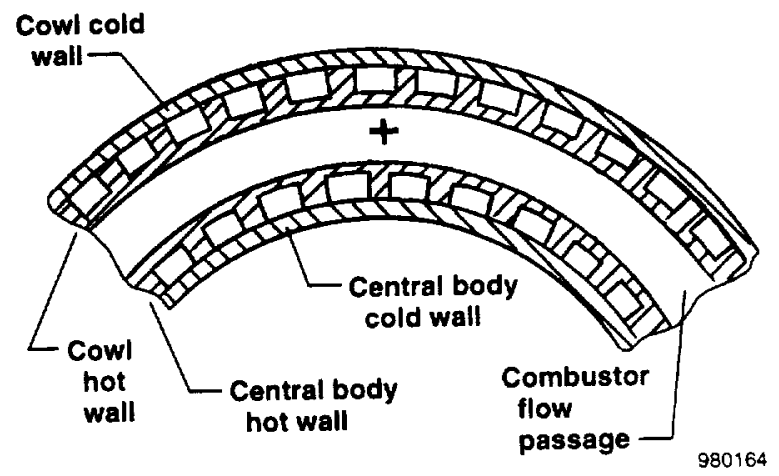

(b) Scramjet model $58 \mathrm{~L}$.

Figure 7. Cross-section of the combustor coolant channel. 
Table 2. Engine characteristics.

\begin{tabular}{lc}
\hline \hline Length (including inlet spike), $\mathrm{mm}$ & 1542 \\
Maximum outside diameter, $\mathrm{mm}$ & 402 \\
Inlet entrance area, $\mathrm{cm}^{3}$ & 400 \\
Weight, $\mathrm{kg}$ & 115 \\
Maximum liquid hydrogen fuel load, $\mathrm{kg}$ & 18 \\
Mach number test range & 3.5 to 6.5 \\
Maximum fuel mass flow rate, $\mathrm{kg} / \mathrm{sec}$ & 0.15 \\
Maximum coolant flow rate, $\mathrm{kg} / \mathrm{sec}$ & $0.3 \pm 0.05$ \\
Inlet ram pressure, $\mathrm{kPa}$ & 50 to 70 \\
Combustor flow pressure, $\mathrm{MPa}$ & $<0.5$ \\
Hydrogen pressure at cooling duct & $2.2+0.3$, \\
entrance, MPa & -0.2 \\
Combustor maximum flow temperature, $\mathrm{K}$ & 2800 \\
Maximum engine operating time, sec & 80 \\
\hline \hline
\end{tabular}

\section{Modification of the SA5 Missile Booster}

Figure 8 shows the SA5 booster with the HFL. This 1960's operational missile was selected by CIAM because of its performance and trajectory compatibility with the experiment requirements of the axisymmetric scramjet. The SA5 has four strap-on solid boosters in addition to the main liquid fuel rocket engine and is launched from a railroad car. The HFL size and weight, basically replacing the original payload, allowed the SA5 to attain its operational maximum speed of Mach 6. Modifications to the missile were intended to push it to aim flight conditions of Mach 6.5 at a dynamic pressure of approximately $1200 \mathrm{lb} / \mathrm{ft}^{2}$ for this fight experiment. These modifications included several weight and drag reduction measures onboard the HFL and the missile, such as reducing the size of the control fins by 75 percent (fig. 9) along with control system changes; increasing the liquid propellant load by $164 \mathrm{~kg}$; and substituting a small, short duration power supply. Overall, hardware weight reduction was about $124 \mathrm{~kg}$ with approximately a 6 -percent reduction in drag. The launch angle was also increased from the original $48^{\circ}$ to $52^{\circ}$.

The 164-kg increase in propellant was achieved by eliminating the normally operationally required tank ullage and by increasing fuel density with low ambient temperatures. These measures required that the launch be carried out within 48 hours after fueling the $S A 5$ rocket. Ambient launch temperature conditions of $-5^{\circ} \mathrm{C} \pm 5{ }^{\circ} \mathrm{C}$ were needed. Allowing a $3-\mathrm{sec}$ extension of main rocket engine operation and an overall thrust impulse increase of about 3 percent was also required.

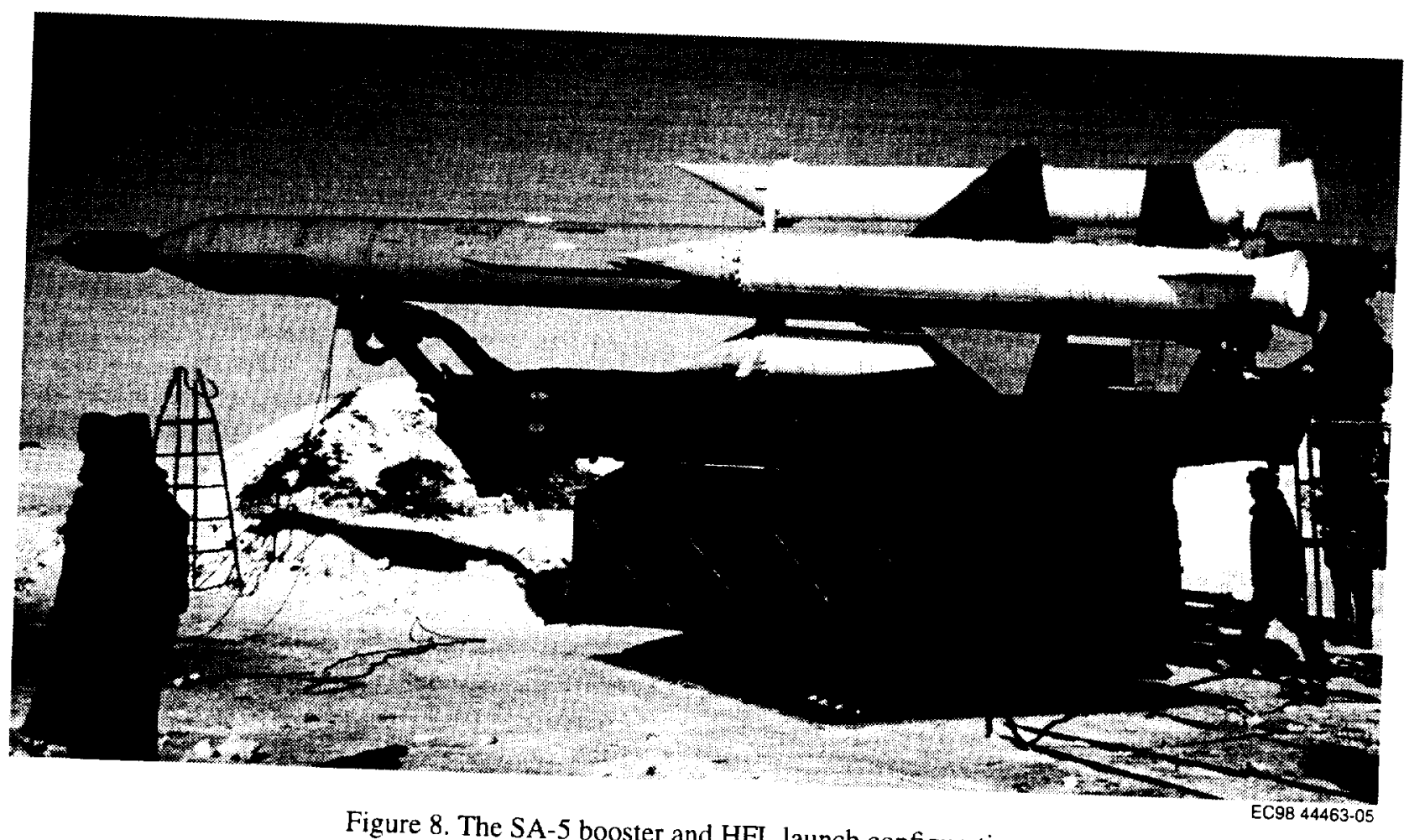

Figure 8. The SA-5 booster and HFL launch configuration. 


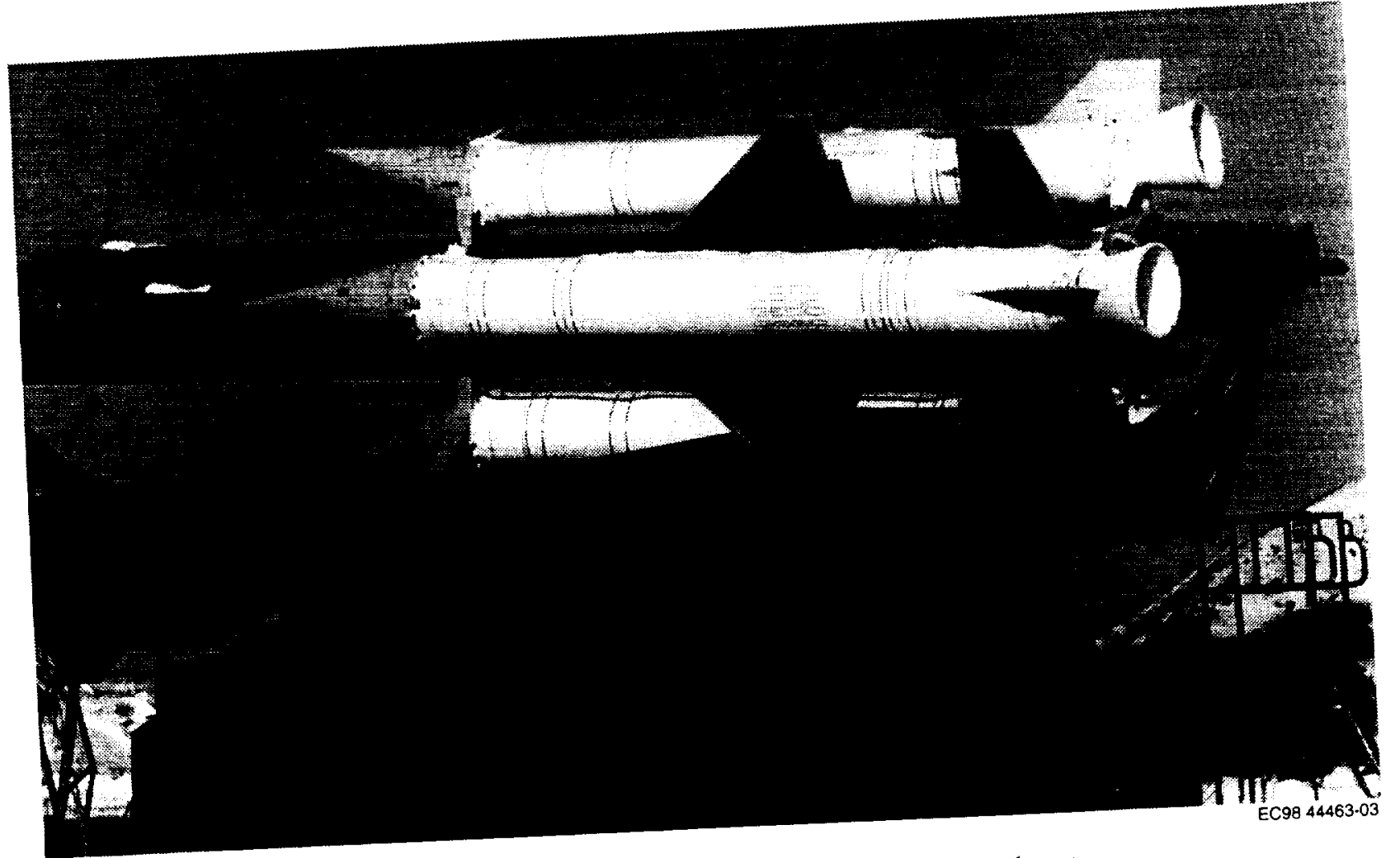

Figure 9. The SA-5 stabilization fin modification and strap-on boosters.

Modifications to the SA5 were checked out in-flight on August 1, 1997, at the Sary Shagan test site. A dummy mockup simulating size and mass of the scramjet engine and HFL was used. The noon launch was at milder ambient temperature conditions of $21^{\circ} \mathrm{C}$. Rocket fuel temperature in the tank was $23^{\circ} \mathrm{C}$, and oxidizer temperature was $22{ }^{\circ} \mathrm{C}$. Nevertheless, Mach 6.20 was achieved in the 116-sec flight. When corrected to planned test launch conditions of $-5^{\circ} \mathrm{C}$, this result indicated that a potential maximum flight $\mathrm{Mach}$ number of $6.5 \pm 0.1$ could be expected.

\section{Launch Preparations and Flight Operations}

Flight launch of the CIAM scramjet took place in the Republic of Kazakstan at the Sary Shagan test range approximately 300 miles north of the city of Almaty on the shores of Lake Balkash (fig. 10). The test range is basically a vast area of flat, semi-arid steppes with large, open launch corridors to the west of the lake toward the Baikonur Space Launch Facility.

Launch preparations began on February 10, 1998, after weather prognosis promised colder temperatures than the unseasonably milder temperatures of $5{ }^{\circ} \mathrm{C}$ experienced on the preceding days. Fueling of the main rocket propellant and oxidizer took place on February 11 as ambient temperature began to drop to $-20^{\circ} \mathrm{C}$ at night and $-10^{\circ} \mathrm{C}$ during the day. The SA5 rocket was carefully fueled in a safe area some $6 \mathrm{~km}$ from the actual launch site and then slowly moved into place later that day to begin prelaunch system checks.

The launch was conducted by Sary Shagan range personnel on February 12 using their mobile launch system consisting of electrical power generators, telemetry, radar, and launch control vehicles. The launch control van also contained real-time telemetry strip charts of selected channels of flight data. The highly trained crew conducted an impressive launch operation under difficult weather conditions.

Fueling of the scramjet began the morning of February 12 under ambient weather conditions of $-15^{\circ} \mathrm{C}$, clear skies, and little or no wind. The first stage of this process consisted of purging the entire engine propellant system of air with gaseous nitrogen. A CIAM-furnished and -staffed gas chromatograph van measured and controlled the purging process until the exhaust gases showed air content less than 0.002 percent was reached. This procedure was followed by purging of the gaseous nitrogen using gaseous hydrogen for about 


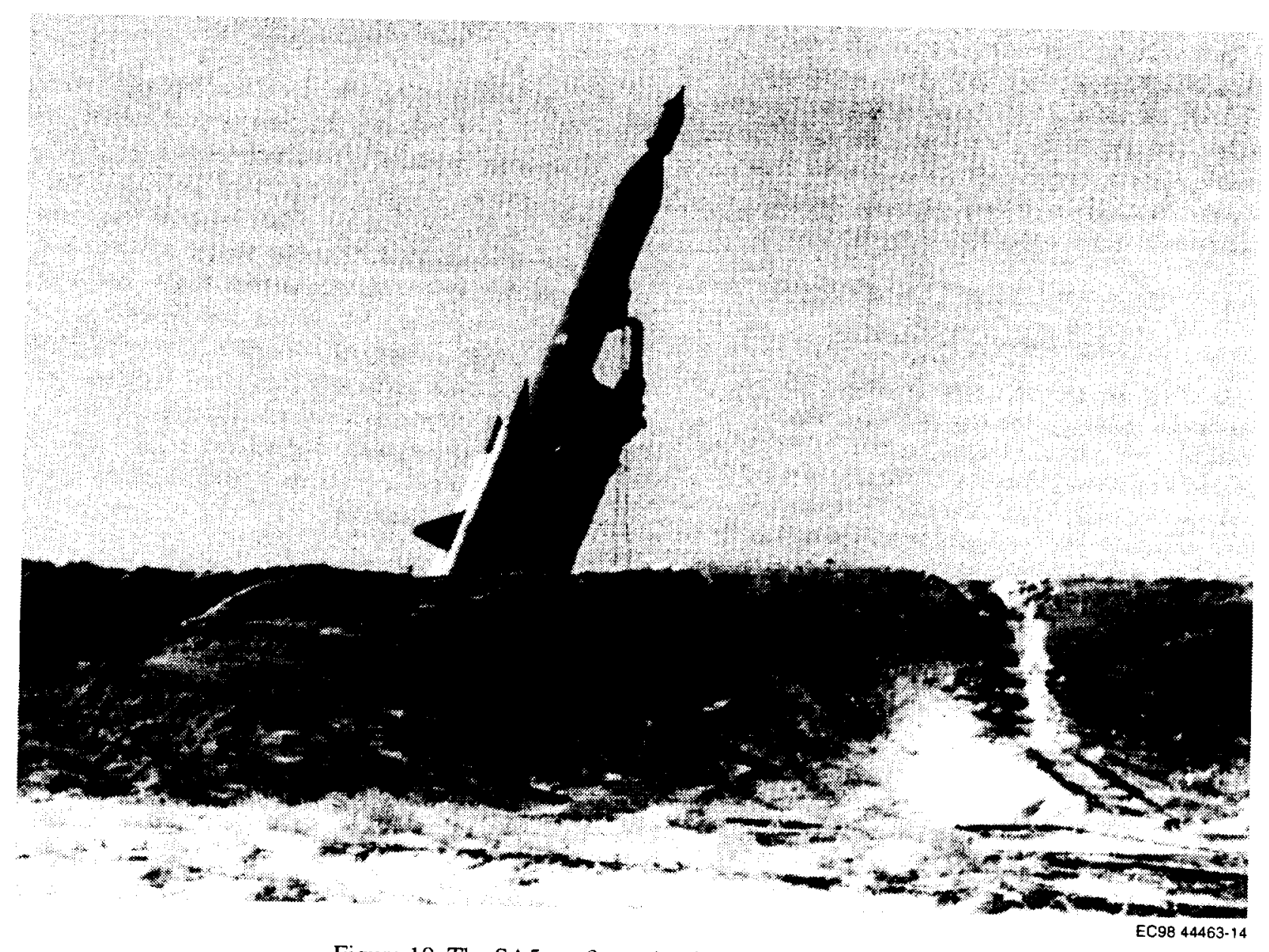

Figure 10. The SA5 configuration in the launch position.

an hour until a gaseous nitrogen level of less than 0.002 percent was likewise achieved as measured by the gas chromatograph. These steps prevented the freezing of air moisture in the system that would have occurred with the direct fueling of liquid hydrogen. It also acted as a safety measure to ensure that all oxygen was removed from the system before the hydrogen was introduced. All fueling was done pneumatically to minimize any electrical system function or possible electrical spark during the fueling phase. The final step of liquid hydrogen fueling took an additional hour to carefully load $18 \mathrm{~kg}$ of fuel onboard. A venting stack was hooked up to pneumatically vent the excess hydrogen fuel as the full fuel loading was reached.

Fueling was completed by noon and followed by two hours of final system checks, launch and range operation checks, and removal of all equipment and personnel from the launch site bunker area. The only external system hooked up to the HFL system during final system checks was a small gaseous nitrogen purge line from the nearby gaseous helium-nitrogen supply cart. The nitrogen purge of the entire HFL system continued right up to launch when an automatic quick disconnect then dropped the purge line from the rocket hookup.

Extensive photography and video filming of the launch system and operation were performed before and after the hydrogen-fueling phase. Range personnel reported that the launch was fully successful, and telemetry and radar operations were completely normal.

Launch of the SA5 was flawlessly carried out at 2 p.m. on February 12 at an ambient temperature of $-10^{\circ} \mathrm{C}$ with a slight breeze from the north. The launch angle was $52^{\circ}$ with the approximately $120-\mathrm{sec}$ flight taking place up to $150 \mathrm{~km}$ downrange to the west. The initial 5-sec boost was carried out by the four strap-on solid rocket boosters (fig. 9). Reduced flow pre-cooling of the scramjet with its liquid hydrogen fuel began $4 \mathrm{sec}$ into the flight. At $18 \mathrm{sec}$ into the ballistic flight, the rocket pitch control autopilot began a pitch down command of $2.3 \mathrm{deg} / \mathrm{sec}$ up 
to $33 \mathrm{sec}$ into the flight. At this point, the constant pitchattitude-depressed trajectory was continued until $57.5 \mathrm{sec}$ into the flight after main rocket engine cutoff at $56 \mathrm{sec}$ into the flight. Thereafter, the autopilot pitch control system was disconnected, and the rocket was allowed to complete a ballistic flight trajectory up to commanded flight termination at $115 \mathrm{sec}$ into the flight.

\section{Scramjet Engine Operation and Preliminary Results}

At $38 \mathrm{sec}$ into the flight, scramjet engine operation and maximum cooling flow rate began as Mach 3.5 was reached. The steam exhaust contrail of the scramjet engine was clearly contrasted with the smaller rocket contrail against the bright blue sky. The contrail and realtime strip chart data confirmed an inlet unstart as the first 1 or $2 \mathrm{sec}$ of fuel injection began. The unstart lasted approximately $10 \mathrm{sec}$ until restart was achieved under continuous fuel injection and remained started for the rest of the flight.

Between 56 and $59 \mathrm{sec}$ into the flight, a Mach number of greater than 6.4 was observed at an altitude of approximately $21.3 \mathrm{~km}$. The aim altitude was $24 \mathrm{~km}$. The lower altitude appears to be a stability and control anomaly that is still being investigated. Maximum altitude achieved during the flight was $27 \mathrm{~km}$.

Contradictory real-time flight data indicated that the first fuel injector station did not operate properly because of either reduced or zero fuel flow. This anomaly is still being analyzed, but the second and third fuel injector stations operated normally in the supersonic internal flow. Preliminary wall pressure measurements and postflight analysis confirm that full supersonic combustion was achieved in the engine. Fueled engine operation continued for some $77 \mathrm{sec}$ until a commanded flight termination at $115 \mathrm{sec}$ into the flight.

Postflight recovery of the scramjet $150 \mathrm{~km}$ downrange from the launch site revealed that the engine survived the flight in one piece except for some overall structural flattening. In-the-field inspection showed no significant burn marks and no burn-throughs in either the inlet or combustor sections. A more thorough postflight inspection of the internal flowpath is planned once the engine is retrieved from the test range impact site.

\section{Concluding Remarks}

This joint Russian-American scramjet flight test effort has focused on pushing the aeronautics frontier of hypersonic air-breathing flight to new levels at Mach 6.5. The first ground and flight test phase of the joint CIAMNASA four-engine scramjet flight program has been successfully completed. Valuable, unique subsonic and long-duration supersonic combustion flight data were obtained from Mach 3.5 to greater than Mach 6.4 at a relatively high range of dynamic pressure flight conditions. Further analysis of ground and flight test data is continuing, serving as a very useful source of data for validating design methods and tools for other present and future programs, such as the United States Hyper-X project currently underway.

Significant modifications to the Hypersonic Flying Laboratory and its scramjet test article, as well as the SA5 launch system have made this flight research system a very valuable source of hypersonic technology information. Russia has established a cost-effective way of developing these scramjet technologies with a complete launch system and flight test infrastructure. Valuable flight and ground test data with identical fullscale engines were obtained to greater than Mach 6.4 to correlate with one another and to improve design methodologies. In addition, real synergy was achieved between CIAM and NASA in sharing design modification assessments, engineering analysis results and other information and ideas.

\section{References}

${ }^{1}$ Roudakov, A.S., Y. Schickhman, V. Semenov, Ph. Novelli, and O. Fourt, "Flight Testing an Axisymmetric Scramjet: Russian Recent Advances," in proceedings of 44th Congress of the International Astronautical Federation, Oct. 16-22, 1993, Graz, Austria.

${ }^{2}$ Roudakov, A., V. Semenov, V. Kopchenov, and C. McClinton, "Comparative Flowpath Analysis and Design Assessment of a Mach 6.5 Axisymmetric Hydrogen Fueled Scramjet Flight Test Engine." AIAA 96-4571, Nov. 1996. 
Public reporting burden for this collection of intormation is estimated to average 1 hour per response, including the time for reviewing instructions, searching existing data sources. gathering and maintaining the data needed, and completing and reviewing the collection of information. Send comments regarding this burden estimate or any other aspect of this collection of information. including suggestions for reducing this burden, to Washington Headquarters Services. Directorale tor information Operations and Reports, 1215 Jetterson Davis Hignway, Suite 1204 , Arlington, VA 22202-4302, and 10 the Ottice of Management and Budget, Paperwork Reduction Project (0704-0188). Washington, DC 20503.

\begin{tabular}{|l|c|c|}
\hline 1. AGENCY USE ONLY (Loave blank) & $\begin{array}{c}\text { 2. REPORT DATE } \\
\text { April } 1998\end{array}$ & $\begin{array}{l}\text { 3. REPORT TYPE AND DATES COVERED } \\
\text { Technical Memorandum }\end{array}$ \\
\hline
\end{tabular}

4. TITLE AND SUBTTTLE Technical Memorandum

Recent Flight Test Results of the Joint CIAM-NASA Mach 6.5 Scramjet Flight Program

6. AUTHOR(S)

WU 242-33-02-00-53-00-RLV

Alexander S. Roudakov, Vyacheslav L. Semenov and John W. Hicks

7. PERFORMING ORGANIZATION NAME(S) AND ADDRESS(ES)

NASA Dryden Flight Research Center

P.O. Box 273

Edwards, California 93523-0273

5. FUNDING NUMBERS

9. SPONSORINGMONITORING AGENCY NAME(S) AND ADDRESS(ES)

10. SPONSORINGMONTORING

AGENCY REPORT NUMBER

National Aeronautics and Space Administration

Washington, DC 20546-0001

NASA/TM-1998-206548

11. SUPPLEMENTAFY NOTES

Presented at the AIAA 8th International Spaceplanes and Hypersonic Systems and Technology Conference, April 27-30, 1998, Norfolk, Virginia. Alexander S. Roudakov and Vyacheslav L. Semenov, Central Institute of Aviation Motors, Moscow, Russia; John W. Hicks, NASA Dryden Flight Research Center, Edwards, CA, USA.

\begin{tabular}{|l|l|l|l|l}
\hline 12a. DISTRIBUTIONAVAILABILTY STATEMENT & 12b. DISTRIBUTION CODE
\end{tabular}

Unclassified-Unlimited

Subject Category 15

13. ABSTRACT (Maximum 200 words)

Under a contract with NASA, a joint Central Institute of Aviation Motors (CIAM) and NASA team recently conducted the fourth flight test of a dual-mode scramjet aboard the CIAM Hypersonic Flying Laboratory, "Kholod." With an aim test Mach 6.5 objective, the successful launch was conducted at the Sary Shagan test range in central Kazakstan on February 12, 1998. Ground-launch, rocket boosted by a modified Russian SA5 missile, the redesigned scramjet was accelerated to a new maximum velocity greater than Mach 6.4. This launch allowed for the measurement of the fully supersonic combustion mode under actual fight conditions. The primary program objective was the flight-to-ground correlation of measured data with preflight analysis and wind-tunnel tests in Russia and potentially in the United States. This paper describes the development and objectives of the program as well as the technical details of the scramjet and SA5 redesign to achieve the Mach 6.5 aim test condition. An overview of the launch operation is also given. Finally, preliminary flight test results are presented and discussed.

14. SUBJECT TERMS

Flight test, Hypersonics technology, SA5 missile booster, Scramjet, Supersonic combustion

\begin{tabular}{|c|c|c|}
\hline $\begin{array}{l}\text { 17. SECUAITY CLASSIFICATION } \\
\text { OF REPOFT }\end{array}$ & $\begin{array}{l}\text { 18. SECUAITY CLASSIFICATION } \\
\text { OF THIS PAGE }\end{array}$ & $\begin{array}{l}\text { 19. SECURTY CLASSIFICATION } \\
\text { OF ABSTRACT }\end{array}$ \\
\hline Unclassified & Unclassified & Unclassified \\
\hline
\end{tabular}

\begin{tabular}{|c|}
\hline $\begin{array}{l}\text { 15. NUMBER OF PAGES } \\
16\end{array}$ \\
\hline $\begin{array}{l}\text { 16. PRICE CODE } \\
\text { A03 }\end{array}$ \\
\hline $\begin{array}{l}\text { 20. LIMTRATION OF ABSTRACT } \\
\text { Unlimited }\end{array}$ \\
\hline
\end{tabular}

